Eduvest - Journal of Universal Studies

\title{
DESCRIPTION OF WASTE MANAGEMENT SYSTEM IN SOE CITY, SOUTH TIMOR REGENCY
}

\author{
Deskrianti Tanaem, Marylin Susanti Junias, Deviarbi Sakke Tira \\ Nusa Cendana University, Indonesia \\ E-mail: destytanaem25@gmail.com,marylin.junias@staf.undana.ac.id, \\ tuamanete@yahoo.co.id
}

\begin{tabular}{|c|c|}
\hline ARTICLE INFO & ABSTRACT \\
\hline $\begin{array}{l}\text { Received: } \\
\text { October, 26 } \\
2021 \\
\text { Revised: } \\
\text { November, } 17^{\text {th }} \\
2021 \\
\text { Approved: } \\
\text { November, } 19^{\text {th }} \\
2021\end{array}$ & $\begin{array}{l}\text { Waste management is a systematic, comprehensive, } \\
\text { sustainable activity that includes waste reduction and } \\
\text { handling. The existence of waste can have a health effect } \\
\text { on the environment and society if it is not handled } \\
\text { seriously. The influence of waste on the environment that } \\
\text { can damage the aesthetics of the environment and for } \\
\text { health can indirectly be in the form of vector-borne } \\
\text { diseases that breed in the waste. This study was } \\
\text { conducted to determine the description of the waste } \\
\text { management system in Soe City. The research method } \\
\text { used is a descriptive survey where the research is carried } \\
\text { out with the main aim of making a picture or description } \\
\text { of a situation objectively. The number of samples in this } \\
\text { study were } 26 \text { TPS and } 1 \text { TPA and the managers of each } \\
\text { TPS and TPA. The analysis used is univariate analysis. } \\
\text { Based on the results of the study, it showed that of the } \\
\text { total } 26 \text { TPS in Soe City, } 3 \text { (11.5\%) were in the good } \\
\text { category, while } 23 \text { (88.5\%) were in the bad category. The } \\
\text { waste management system that starts from waste sorting } \\
\text { is } 26 \text { (100.0\%) TPS is bad in sorting waste, bad waste } \\
\text { collection is } 17 \text { (65.4\%) while good is } 9 \text { TPS (34.6\%). The } \\
\text { process of transporting waste from TPS to TPA is still bad } \\
\text { at } 17 \text { (65.4\%) TPS and } 9 \text { (34.6\%) TPS have good category, } \\
\text { for waste processing from } 26 \text { TPS no one does waste } \\
\text { processing, and final waste processing Soe City TPA is still }\end{array}$ \\
\hline & $\begin{array}{l}\text { Deskrianti Tanaem, Marylin Susanti Junias, Deviarbi Sakke } \\
\text { Tira.(2021). Description of Waste Management System in Soe City, } \\
\text { South Timor Regency. Journal Eduvest. 1(11): 1366-1373 }\end{array}$ \\
\hline $\begin{array}{l}\text { How to cite: } \\
\text { E-ISSN: } \\
\text { Published by: }\end{array}$ & $\begin{array}{l}2775-3727 \\
\text { https://greenpublisher.id/ }\end{array}$ \\
\hline
\end{tabular}




bad at destroying waste. The Soe City Government is
expected to pay attention to waste management issues as
well as support and facilitate the solid waste
management system in Soe City, in order to reduce the
negative impact on environmental health and public
health.

\section{INTRODUCTION}

Environmental health is an environmental condition that greatly influences the ecological balance between humans and their environment. A healthy environment supports the achievement of a healthy and happy quality of human life (Saputro, Mandalia, \& Putri, 2015). One of the environmental problems that is quite serious in the world is the problem of waste. Garbage is something that is not used, not used, not liked or something that has been thrown away that comes from human activities and does not happen by itself (Dea, 2018). The presence of waste will have an impact on public health because it is a source of transmission of congenital diseases by vectors that live in waste such as flies (Sumantri, 2015). Waste must be managed as small as possible so as not to disturb and threaten public health. Good waste management is not only for the sake of health but for the beauty of the environment (Sulistiyorini, Darwis, \& Gutama, 2015). Waste management in Indonesia has become an actual problem along with the increasing rate of population growth which has an impact on the increasing amount of waste produced. The problems faced in waste management in Indonesia, including the lack of a firm legal basis, inadequate waste disposal sites, lack of effort in composting, and lack of landfill management with the right system (Mahyudin, 2017).

Law No. 18 of 2008 concerning waste management is carried out with two main focuses, namely waste reduction and handling. Waste reduction as described in the aforementioned Laws and Government Regulations is carried out starting from the source of the waste to the final management. Where waste reduction is realized by the active involvement of the community and waste management. Reducing your own waste with the $3 \mathrm{R}$ process (Reduce, Reuse, Recycle). This is because until now the $3 \mathrm{R}$ process is considered the most suitable in reducing waste generation by $15-20 \%$. Waste management can be assumed that the rate of waste production is not proportional to the handling process. This certainly spurs local governments to think early on how to have an efficient strategy in tackling the problem of solid waste. 7 In the capacity of the city as a source of fulfilling human needs, it is necessary to provide various facilities and infrastructure that are adequate in preserving the environment through good waste management (Rizal, 2011).

South Central Timor Regency with the capital city Soe is one of the densely populated urban areas. Based on data from the TTS BPS, the total population in TTS Regency is 459,959 people. Besides that, the population density of Soe City itself is 35,668 people. The large number of residents in TTS Regency in general and in Soe City in particular will certainly cause social problems, one of which is the waste problem. According to data obtained from the Cleanliness and Gardening Unit of the TTS Regency, the number of TPS scattered in the Soe City area is 26, and for the operating 
TPA there is 1 . The amount of waste transported per day is $\pm 50 \mathrm{~m} 3$. The volume of waste continues to increase every year, namely in 2017 the volume of waste was 9,791 M3, in 2018 the volume of waste increased by 11,987 M3 and in 2019 there was still an increase of 14,175 M3 and the most waste was generated from public places (Manalu \& Purba, 2020).

A preliminary survey conducted by researchers at several TPS in Soe City was that the sanitation conditions of the TPS were poor, and the waste sorting and collection had not been carried out, causing piles of garbage to be uncontrolled and obstructing the view. In addition, residents around the temporary shelters are also affected by the presence of insects and the pungent smell of garbage when passing through the TPS. Garbage problems that are not handled properly, apart from damaging environmental health, can also affect public health.

\section{RESEARCH METHOD}

The type of research used is a descriptive survey. The descriptive survey method is a research method that is carried out with the main aim of making a picture or description of a situation objectively (Notoatmodjo, 2012). This research was conducted in Soe City in August-September 2021. The sample in this study was all TPS in Soe City, totaling 26 and 1 operating TPA, as well as waste management at each TPS and TPA. The data analysis used is univariate analysis.

\section{RESULT AND DISCUSSION}

Table 1. The results of the univariate analysis of the conditions of the Soe City Temporary Shelters (TPS) in 2021

\begin{tabular}{cll}
\hline Temporary Shelter & Frequency & Percentage $(\%)$ \\
\hline Bad & 23 & $88,5 \%$ \\
Good & 3 & $11,5 \%$ \\
\hline Total & 26 & 100,0 \\
\hline
\end{tabular}

Table 1 shows that the conditions of Soe City TPS that are in the good category are $3(11.5 \%)$ and $23(88.5 \%)$ of the total 26 TPS in Soe City have a bad category.

Table 2. Waste Segregation at the Soe City Temporary Shelter in 2021

\begin{tabular}{cll}
\hline Waste transportation & Frequency & Percentage (\%) \\
\hline Bad & 26 & 100,0 \\
Good & 0 & 0,0 \\
\hline Total & 26 & 100,0 \\
\hline
\end{tabular}

Table 2 shows that of the total TPS in Soe City, which amounted to $26(100.0 \%)$ TPS are bad at sorting waste.

Table 3. Garbage Collection in Soe City Temporary Shelters in 2021

\begin{tabular}{lll}
\hline Waste transportation & Frequency & Percentage $(\%)$ \\
\hline Bad & 17 & $65,4 \%$ \\
Good & 9 & \\
Total & 26 & $34,6 \%$ \\
\hline
\end{tabular}




\section{Deskrianti Tanaem, Marylin Susanti Junias, Deviarbi Sakke Tira}

Table 3 shows that the garbage collection at the Soe City TPS which is good at collecting waste is 9 TPS $(34.6 \%)$ less than the bad in collecting waste, which is 17 TPS $(65.4 \%)$.

Table 4. Waste transportation in temporary shelters in Soe City in 2021

\begin{tabular}{lll}
\hline Waste transportation & Frequency & Percentage $(\%)$ \\
\hline Bad & 17 & $65,4 \%$ \\
Good & 9 & $34,6 \%$ \\
\hline Total & 26 & 100,0
\end{tabular}

Table 4 shows that the transportation of waste from TPS to TPA has good categories, namely $9(34.6 \%)$ and those who are bad in transporting waste are 17 TPS $(65.4 \%)$.

Table 5. Waste Processing at the Soe City Temporary Shelter in 2021

\begin{tabular}{lll}
\hline Waste transportation & Frequency & Percentage (\%) \\
\hline Bad & 26 & $100,0 \%$ \\
Good & 0 & $0,0 \%$ \\
\hline Total & 26 & 100,0 \\
& & \\
\hline
\end{tabular}

Table 5. It can be seen that the waste processing at TPS Soe City has a bad category, namely 26 TPS (100.0\%) that do not do waste processing.

Table 6. waste disposal at the final processing site of Soe City in 2021

\begin{tabular}{lll}
\hline Waste transportation & Frequency & Percentage (\%) \\
\hline Bad & 1 & $100,0 \%$ \\
Good & 0 & $0,0 \%$ \\
\hline Total & 1 & 100,0
\end{tabular}

Table 6. shows that waste destruction at the Soe City TPA has a bad category because no waste destruction is carried out.

\section{Discussion}

1. Temporary Shelter in Soe City

Temporary waste collection site (TPS) is a place where waste is disposed of and temporarily collected until it is transported to a final waste disposal site. Sanitation of temporary waste shelters is an effort to monitor and prevent losses as a result of the utilization and products of temporary waste storage which are closely related to the emergence or transmission of diseases.

The results of research conducted at TPS Soe City based on interviews and observations showed that the condition of temporary shelters in Soe City from a total of 26 TPS only 3 TPS that met the criteria set by the regulation of the minister of public works in 2013. The sanitary conditions of temporary shelters are still said to be bad because most of the temporary storage tanks in Soe City have been damaged but are still used by the community. In addition, the size of the garbage collection tanks is only 3 which has a size of $200 \mathrm{~m} 2$, and on average all temporary storage tanks in Soe City do not 
have a cover. The poor condition of the TPS causes a lot of garbage to be still scattered around the TPS and the absence of a cover is what causes the waste generated at the TPS to emit a strong odor when passing through the TPS.

1. Garbage Segregation at Temporary Shelters in Soe City

Waste sorting is one of the processes in waste processing, namely separating into certain waste groups. Garbage segregation carried out by the community before disposing of waste to the TPS. Garbage must be separated at the household to facilitate the process of processing waste. Waste sorting means separating organic, inorganic and B3 waste so that it should encourage recycling efforts in the processing process. The results showed that the waste sorting in 26 Temporary Shelters in Soe City $26(100.0 \%)$ was poor in sorting waste. Waste sorting at TPS is still bad because there are no facilities that distinguish the types of waste so that people who throw garbage into TPS do not sort waste before it is disposed of, and there is no special order from UPT Cleansing and Landscaping to officers to sort waste.

This research is in line with research conducted by Istiqomah in 2018 on the factors that influence waste generation at TPS in Madiun City which explains that of the total TPS in Madiun City which amounted to 40, only 10 (25.0\%) did waste sorting and $30(75.0 \%)$ are bad at sorting waste. Waste segregation is a very important stage in waste management and processing. Waste processing will be hampered if you do not sort waste, so it is necessary to re-separate if the waste is still mixed between recyclable organic waste and non-recyclable inorganic waste (Kurniaty, Nararaya, Turawan, \& Nurmuhamad, 2016).

\section{Garbage Collection at Temporary Shelters in Soe City}

Garbage collection is a form of collecting and transferring waste from the waste source to the TPS. Waste collection activities are carried out by managers of residential areas, commercial areas, industrial areas, public facilities, social facilities, and other facilities as well as district/city governments that have been appointed by the Environmental Service at each TPS. In the process of collecting waste, it must be accommodated in containers that have been provided separately according to the type of waste that has been sorted (Mitoriana Porusia, 2021).

The results showed that 17 TPS $(65.4 \%)$ were bad at collecting waste and 9 TPS (34.6\%) were good at collecting waste. Garbage collection at 17 TPS is still poor because collection is not carried out according to the schedule set at TPS. In addition, the community does not pay attention to the schedule for collecting waste at the TPS, so they throw away the garbage after the officers collect the garbage. Another obstacle faced by officers when collecting waste is the limited number of garbage collection trucks used, which have a small container size so that they cannot accommodate waste in one go while the officers are limited in the cost of fuel for garbage collection trucks. In addition, the condition of the garbage collection trucks used at the UPT Hygiene and Gardening is an old truck so that it often gets disturbed or damaged so that it hinders officers from collecting garbage. Garbage collection will be carried out again when the truck has been repaired and this can take days or a week, resulting in the generation of uncollected waste piling up in some of these TPS. Meanwhile, 9 TPS in waste collection are good because the people who use TPS pay attention to the time of waste collection and dispose of it according to the scheduled time so that when the officers carry out waste collection, the community immediately comes to throw their waste into the TPS and does not result in waste is scattered or scattered after collection. The trucks used for these 9 TPS are large trucks so that they can accommodate large amounts of waste at once. This research is in 


\section{Deskrianti Tanaem, Marylin Susanti Junias, Deviarbi Sakke Tira}

line with research conducted by Istiqomah in 2018 on factors related to waste generation at the Madiun City TPS, namely from a total of 40 TPS that collected waste properly 12 TPS $(30.0 \%)$.

The indirect impact of waste generation is in the form of vector-borne diseases that breed in the waste, while it also causes environmental pollution. The collection of garbage that is not transported will be used by flies as a place to live. It is known that flies are vectors for stomach diseases including diarrhea, cholera, dysentery, typhoid (Praditya, 2012).

3. Garbage transportation

Transportation is the activity of bringing waste from the source or temporary shelter to an integrated waste processing site or final processing site (TPA) by using a motorized vehicle designed to transport waste. Based on the results of the research on waste transportation in 26 temporary shelters, 17 TPS $(65.4 \%)$ were bad at transporting waste and 9 TPS (34.6\%) were good at transporting waste. Waste removal and transportation is intended as an operation activity starting from the last collection point of a collection cycle to the TPA or TPST at collection with a direct individual pattern or from a temporary transfer/storage site (TPS) or communal shelter to the final processing/processing site. (TPA/TPST). The method of transportation and the equipment to be used depend on the collection pattern used.

Research on the transportation of waste from TPS to TPA Kota Soe showed that $17(65.4 \%)$ TPS were bad at transporting waste, while $9(34.6 \%)$ were good at transporting waste. Based on observations by researchers, it was found that the transportation of waste was poor because the transportation of waste was only carried out for five working days, namely Monday-Friday, Saturday and Sunday, no transportation was carried out, resulting in high waste generation at several TPS and a lot of garbage scattered while not being transported. Other obstacles faced by waste management officers are the limited number of waste transport facilities, the small size of garbage trucks and the limited fuel costs for trucks so that officers have to transport waste to the TPA in one go regardless of the frequency of waste in the TPS. While the 9 TPS that are good at transporting waste are because the garbage trucks used by the officers at the TPS are large trucks capable of transporting large amounts of waste in one go. In addition, the condition of the truck is still in a new condition so that it does not experience problems when transporting garbage. This study is in line with research conducted by (Arief, 2018) on the relationship between waste management and the density level of flies in the temporary shelter (TPS) of Madiun City in 2018 which obtained results from 40 TPS as many as $26(65.0 \%)$ poor in transporting waste., while $14(35.0 \%)$ are good at transporting waste (Arief, 2018).

\section{Waste processing}

Waste processing is an effort to reduce the volume of waste or change its form to be more useful. Among others, by reducing, sorting, collecting, transporting, processing, to reduce the amount of waste generated in the landfill. Waste processing carried out at the TPS must be in accordance with the characteristics of the waste disposed at the TPS so that processing is possible. B3 waste will be managed according to regulations, while inorganic waste such as plastic, paper, metal/glass can be reused as recycled material, and organic waste will be used as raw material for composting. The results of research on waste processing in 26 Temporary Shelters in Soe City show that all 26 TPS (100.0\%) are bad at processing waste and there are no TPS that are good at processing waste. Waste processing at the TPS is still bad due to the absence of a special order from the UPT for 
Hygiene and Landscaping to the Officers to carry out waste processing. The results of this study are in line with the research conducted by 3 regarding the factors related to waste generation at the Madiun City TPS in 2018, which resulted from a total of 40 TPS that carried out waste processing as many as $18(45.0 \%)$ TPS, while $22(55.0 \%)$ is bad at processing waste.

Waste management must be done properly because waste is very dangerous for human health and the surrounding environment. (Biofarm) Waste processing can be done by recycling. Recycling of waste must be done with the right method so that it does not interfere with human health human. Not all trash is said to be useless, some trash that has been thrown away can still be reused (Sari \& Anggoro, 2020)

5. Waste final processing

Final waste processing is the process of returning waste and or residues from previous waste processing to safer environmental media (Amalia, Hadisantoso, Wahyuni, \& Supriatna, 2020). Research results Final processing of waste at the Soe City Final Disposal Site (TPA) is still poor in destroying waste. It is said to be bad because the final processing of the waste at the Soe City TPA was not carried out according to the methods of the UPT Cleansing and Landscaping. The method used to destroy waste is a sanitary landfill (hoarding waste with soil and grinding it using heavy equipment) but this method is not carried out at the TPA so that the waste that has been transported from the TPS accumulates in large quantities. When the researchers made direct observations to the landfill, the condition was very dangerous for public health because the smell from the pile of garbage was very strong and there were very many vectors of disease transmission. When conducting an interview with the TPA manager, the destruction is still bad because of the limited number of facilities and infrastructure used to destroy waste, the unavailability of tools and materials for destruction, this results in the waste not being destroyed for months and only being left to pile up in the TPA so that if left alone it will have an impact. bad for the environment and the people who live around the landfill.

Handling of waste in open dumps for final processing is prohibited, as this method can cause several negative impacts on the environment and public health. In landfilling with an anaerobic landfill system, it will generate leachate in the tibulan layer and will seep into the soil layer below. This leachate will damage and produce a very strong stench and disturb the community around the TPA (Axmalia \& Mulasari, 2020).

\section{CONCLUSION}

Based on research and discussion, it can be concluded that waste management in Soe City as a whole has not been implemented properly. Waste management has not been implemented from upstream to downstream or from TPS to TPA is a serious problem if it is not handled properly. So it is hoped that with this research, the Soe City Government can support the Office related to waste management by increasing the number of facilities and infrastructure as well as training on waste management so that they can carry out good and useful waste management in order to reduce the negative impact on public health and also the environment.

\section{REFERENCES}

Amalia, Vina, Hadisantoso, Eko Prabowo, Wahyuni, Ira Ryski, \& Supriatna, Adi Mulyana. (2020). Penanganan Limbah Infeksius Rumah Tangga Pada Masa Wabah Covid-19. Lp2m. 
Arief, Setyo Syahputro. (2018). Hubungan Pengelolaan Sampah Dengan Tingkat Kepadatan Lalat Di Tempat Penampungan Sementara (Tps) Kota Madiun.

Axmalia, Astry, \& Mulasari, Surahma Asti. (2020). Dampak Tempat Pembuangan Akhir Sampah (Tpa) Terhadap Gangguan Kesehatan Masyarakat. Jurnal Kesehatan Komunitas, 6(2), 171-176.

Dea, Nisa'istiqomah. (2018). Faktor-Faktor Yang Mempengaruhi Timbulan Sampah Di Tempat Penampungan Sementara (Tps) Kota Madiun.

Kurniaty, Yulia, Nararaya, Wahyu Haji Bani, Turawan, Ranatasya Nabila, \& Nurmuhamad, Fendy. (2016). Mengefektifkan Pemisahan Jenis Sampah Sebagai Upaya Pengelolaan Sampah Terpadu Di Kota Magelang. Varia Justicia, 12(1), 135-150.

Mahyudin, Rizqi Puteri. (2017). Kajian Permasalahan Pengelolaan Sampah Dan Dampak Lingkungan Di Tpa (Tempat Pemrosesan Akhir). Jukung (Jurnal Teknik Lingkungan), 3(1).

Manalu, Frencilyka, \& Purba, Tiurniari. (2020). Analisis Kebijakan Pengelolaan Sampah Melalui Program Bank Sampah Kota Batam. Jurnal Akrab Juara, 5(3), 12-24.

Mitoriana Porusia, S. K. M. (2021). Kajian Literatur Hubungan Antara Pengetahuan Dan Sikap Pedagang Dengan Pengelolaan Sampah Di Pasar. Universitas Muhammadiyah Surakarta.

Notoatmodjo, Soekidjo. (2012). Metodologi Penelitian Kesehatan.

Praditya, Oktyan. (2012). Studi Kualitatif Manajemen Pengelolaan Sampah Di Kelurahan Sekaran Kota Semarang. Unnes Journal Of Public Health, 1(2).

Rizal, Mohamad. (2011). Analisis Pengelolaan Persampahan Perkotaan (Sudi Kasus Pada Kelurahan Boya Kecamatan Banawa Kabupaten Donggala). Smartek, 9(2).

Saputro, Anggoro Purwo, Mandalia, Sekar Arum, \& Putri, Berlian Primadani Satria. (2015). Strategi Csr Internal Pt. Bio Farma Bandung (Studi Deskriptif Pada Implementasi Program Uji Emisi Kendaraan Pt Bio Farma Periode 2014-2015). Eproceedings Of Management, 2(3).

Sari, Chanif Kurnia, \& Anggoro, Sarni. (2020). Edukasi Dampak Pengelolaan Sampah Sebagai Upaya Peningkatan Pemahaman Siswa Tentang Gerakan Masyarakat Hidup Sehat. Jurnal Peduli Masyarakat, 2(2), 41-48.

Sulistiyorini, Nur Rahmawati, Darwis, Rudi Saprudin, \& Gutama, Arie Surya. (2015). Partisipasi Masyarakat Dalam Pengelolaan Sampah Di Lingkungan Margaluyu Kelurahan Cicurug. Share: Social Work Journal, 5(1).

Sumantri, H. (2015). Metodologi Penelitian Kesehatan. Prenada Media. 